\title{
MENYOAL ALAM, MENJELMA PEREMPUAN: KARNAVAL KULTURAL CERITA RAKYAT MORONENE
}

\author{
La Ode Gusman Nasiru
}

\author{
Dosen Sastra Indonesia, Fakultas Ilmu Budaya, Universitas Haluoleo \\ Kendari, Sulawesi Tenggara \\ laode.gusman.n@mail.ugm.ac.id
}

\begin{abstract}
Abstrak
Penelitian ini berfokus pada tokoh dalam tiga cerita rakyat suku Moronene yang berjudul: Tina Lungo(TIL); Unsono Nee Taubonto (UNT); dan Duu-duuno Rema yi Kotu'a(DRK). Dengan menggunakan teori ekofeminisme, penelitian ini membedah posisi laki-laki dan perempuan dalam komunal etnis Moronene dan sejauh mana masyarakat Morone mengaplikasikan penghayatan terhadap alam. Konsep kerja menggunakan metode analisis deskriptif kualitatif. Analisis dilakukan setelah mendeskripsikan data-data yang sudah diidentifikasi lewat proses pembacaan. Hasilnya, laki-laki sengaja dideskripsikan dengan citra yang gamang, miskin, dan penuh nafsu amarah. Berbeda halnya dengan perempuan, yang mampu menghayati benar kemanunggalannya dengan alam, mereka dilimpahi keistimewaan-keistimewaan yang menghidupi, menjaga, mencintai. Simpulannya, manusia perlu berjalan beriringan dengan alam demi menciptakan peradaban dunia. Ketiga cerita layak diberikan kepada anak-anak dalam konsep dongeng dan pengantar tidur. Ini penting agar mereka memiliki kesadaran ekologis dan gender, sehingga kelak mereka menjadi manusia-manusia yang membawamisi perdamaian bagi seluruh semesta.
\end{abstract}

Kata Kunci: Moronene, ekofeminisme, cerita rakyat, perempuan

\section{Reviewing Nature, Managing Women: Cultural Carnaval of Moronene Folktales}

\begin{abstract}
This researchfocuses on the characters in the three stories of the Moronene people, entitled: Tina Lungo (TIL); Unsono Nee Taubonto (UNT); and Duu-duuno Rema yi Kotu'a (DRK). Using the theory of ecofeminism, this research examines the position of men and women in the Moronene ethnic communal and the extent to which the Moronene community applies their appreciation of nature. The work concept uses a qualitative descriptive analysis method. The analysis was carried out after describing the data that had been identified through the reading process. As a result, men are deliberately described with an image that is giddy, poor, and full of anger. Unlike the case with women, who can fully appreciate their oneness with nature, they are endowed with features that nurture, care for, love. In conclusion, humans need to go hand in hand with nature to create world civilization. The three stories are worth giving to children in the concept of fairy tales and bedtime. This is important so that they have ecological and gender awareness so that one day they become human beings who carry the mission of peace for the entire universe.
\end{abstract}

Keywords: Moronene, eco-feminism, folktales, women

\section{PENDAHULUAN}

Perempuan itu bernama Zarah. Ayahnya, Firas, lelaki yang terafeksi terhadap fungi, menularkan euforia jejamuran terhadap anak perempuannya. Mewariskan segenap kemampuannya menaklukkan Bukit Jambul, pusat kekuatan mistik di tempat mereka hidup. Hingga kelak Zarah menunjukkan bakat yang luar biasa besar dalam upaya bersahabat dengan alam. Ia mampu merangkul seekor anak orang utan di 
jantung Kalimantan yang kehilangan induk; selamat dari maut yang menari di rahang empat kawanan singa di sebuah oasis di Kenya. Zarah menunjukkan puncak kesadarannya tentang dari mana ia berasal, yaitu alam.

Dewi Lestari memuat lakon tersebut dalam novelnya Partikel. Kisah tentang dua tokoh dari dua gender, lakilaki dan perempuan, dihadirkan sebagai subjek dengan relasi yang ketat dalam lingkar spiritualitas alam dan manusia. Narasi tentang Zarah dan Firas pernah saya presentasikan di depan forum Konferensi Internasional Kesusastraan di Yogyakarta, Oktober 2016. Dalam makalah yang berjudul "Membincang Ekofeminisme yang Ramah Gender dalam Partikel Karya Dewi Lestari", saya melihat bahwa isu besar yang coba disuarakan kelompok studi feminisme, dalam hal ini gatra yang berkaitan dengan riset ekologi, tentang diferensiasi perempuan-alam versus lakilaki-budaya tampaknya tidak berlaku dalam novel teranalisis. Artinya, Dewi Lestari berhasil menekan ketakutan fraksi ekofeminis yang mereka letakkan sebagai hipotesis, sekaligus mencapai apa yang menjadi mimpi besar kelompok disiplin termaksud.

Ini kabar gembira, tentu saja, sebelum akhirnya saya harus berhadapan dengan kenyataan kontestasi laki-laki dan budaya yang beroposisi dengan perempuan dan alam juga menjadi bagian dari kolektif ideologi masyarakat Moronene, dengan aksentuasi yang cukup berbeda. Cerita terkaji yang memuat gagasan tentang pertarungan-pertarungan itu termaktub dalam tiga cerita rakyat Moronene yang berkembang di pelosok Kabupaten Bombana dan Pulau Kabaena, Sulawesi Tenggara. Masing-masing berjudul: Tina Lungo, Unsono Nee Taubonto, dan DuuDuuno Rema yi Kotu'a. Ketiganya selanjutnya disingat TIL, UNT, dan DRK.

TIL berkisah tentang seorang pemuda yang suatu ketika menemukan mangkuk di tengah kebun yang sedang ia garap. Mangkuk menjelma putri cantik yang saban hari diam-diam memasak untuk menandaskan rasa lapar sang pemuda. Mengetahui hal itu, sang pemuda memaksa menikah. Putri cantik mengajukan syarat. Hingga syarat itu dilanggar, sang putri kembali ke kayangan. Ia turun ke bumi dalam wujud hujan.

Seorang lelaki tua bernama Ayah Kuma sehari-hari bekerja mencari umbiumbian. Suatu hari ia bertemu putri cantik, Wa'uraa. Wa'uraa berpesan agar si kakek pulang dan membersihkan tempat penyimpanan beras. Secara ajaib tempat itu pun penuh terisi butiran gabah. Lelaki tua juga menanam bibit padi yang diberikan. Padi tumbuh melimpah. Beberapa pemuda yang membantunya bahkan tak sanggup menghabiskan limpahan padi. Sebagian yang membusuk dibiarkan tak terurus. Kisah ini terangkum dalam UNT.

Sementara itu, DRK membentangkan alur hidup Putri Warema yang kencantikannya membius para ksatria. Para jawara rela bertarung demi memperistrinya. Sang putri mengambil keputusan mengakhiri hidup demi mencegah pertumpahan darah. Ia tidak mati begitu saja. Pusaranya menjadi musabab tumbuh suburnya sebatang pohon enau. Pohon yang semua bagiannya bernilai guna bagi siapa saja. Darinya, rongga kehidupan berdenyut.

Ketiga ringkasan cerita diikat oleh satu bentuk niscaya, perempuan dalam kolaborasinya menjadi sumber bagi segala sendi kehidupan. Kenyataan ini menghadirkan satu diskursus tentang kesadaran perempuan terhadap muasal dan tujuan mereka: alam. Di sinilah perbincangan ini bermula. Pasal inilah yang mengantarkan kita pada pertanyaan: 1) Bagaimana masyarakat Moronene menempatkan laki-laki dan perempuan dalam cerita rakyatnya? 2) Bagaimana masyarakat Moronene memandang alam dalam arena kulturalnya?

Lazim dipahami betapa masyarakat Indonesia termasuk dalam kelompok sosial patriarki. Hampir semua sendi kehidupan 
dikuasai laki-laki dan budaya yang mengunggulkan peran laki-laki sebagai pengambil keputusan. Penelitian ini selanjutnya memiliki dua tujuan utama. Pertama, untuk melihat posisi laki-laki dan perempuan dalam masyarakat Moronene. Kedua gender ini apakah masih terkungkung dalam nuansa disparitas atau telah terbebas dari motif demikian. Kedua, untuk melihat sejauh mana masyarakat Moronene mengaplikasikan penghayatan mereka terhadap alam. Dengan begitu, kita dapat dengan terang menilai relasi antara alam dan kultur masyarakat terkaji.

Moronene merupakan sebutan untuk etnis tertua yang mendiami sisi Selatan pulau Sulawesi Tenggara. Nama Moronene, dilansir dari penelitian Rambe(1969), juga tercatat sebagai sebuah kerajaan yang membawahi beberapa daerah yang terbentang sepanjang Kabaena, Rumbia, Poleang, dan Kolaka. Daerah-daerah tersebut selanjutnya berkembang menjadi kecamatan, sebelum akhirnya, padatahuntahun berikutnya, daerah ini mengalami pemekaran menjadi Kabupaten Bombana dan Kabupaten Kolaka. Kerajaan Moronene masa lalu berada di bawah kontrol Kesultanan Buton.

Bombana, tempat berdiam masyarakat Moronene, menggemparkan tanah air di tahun 2008. Betapa tidak, tahun-tahun itu menjadi mimpi manis sekaligus mimpi buruk bagi masyarakat Bombana setelah ditemukan emas murni yang terkandung di dalam perut buminya. Sejak itu, masyarakat Bombana berbondong-bondong meninggalkan pekerjaan di ladang-ladang pertanian, perkebunan, perikanan, untuk beramairamai mendulang emas. Masyarakat nonMoronene yang berasal dari luar kabupaten pun berduyun-duyun merangsek ke Bombana. Mendulang hidup, menggapai mimpi. Menyisakan peristiwa tragis dan tragedi tersendiri bagi masyarakat dan alam Moronene. Moronene yang kaya dengan hasil alam, dan berjaya dalam tradisi, spiritualitas, dan gerak kultural.

Setakat ini, belum ada satu pun penelitian ilmiah yang menelaah pertautan cerita rakyat Moronene dengan studi ekofeminisme. Saya hampir menyerah menemukan penelitian yang relevan terkait objek terkaji. Hingga akhirnya beberapa artikel dan karya ilmiah, menyelamatkan upaya saya.

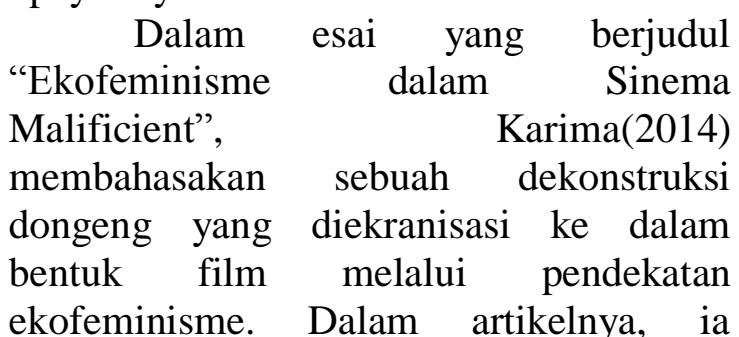
menulis besi sebagai kelemahan tokoh utama. Ini menarik, sebab besi menjadi simbol dari revolusi industri, satu etape sejarah dunia yang secara intrinsik melupakan alam dalam proses manusia menjalani kehidupannya. Hal lain yang tidak kalah urgen adalah upaya kuat dari tokoh utama perempuan yang menolak kekerasan sebagai jalan memperoleh kedamaian. Kedua nilai ini masih dibumbui dengan resistensi tokoh dari ideologi maskulin yang memaksakan ciuman pangeran asing sebagai satusatunya unsur penyelamat bagi perempuan.

Kajian tentang ekofeminisme yang bertautan dengan dongeng juga terinternalisasi dalam skripsi Reni Agustina. Mahasiswa sastra Jerman, UNY, ini mendedahkan citra perempuan dalam kumpulan cerpen Bruder Grimm (2012). Sayangnya, penelitian ini tergelincir pada sebatas aksentuasi citra dan nilai keperempuanan. Bisa dimengerti, pengkajian demikian sudah cukup memenuhi prasyarat menjadi sarjana(Agustina, 2012).

Penulis lainnya, Elly Wuriyani menulis artikel tentang Opera Batak di Pinggir Danau dengan menggunakan tinjauan ekofeminisme. Hasil dari penelitian ini menggambarkan bagaimana perempuan dimitoskan dengan alam sampai pada yang mengingkari alam. 
Namun demikian, ada pandangan yang kontras dalam diri perempuan maupun antarindividu. Hasilnya, zaman dan kuasa mempunyai peluang dalam menciptakan mitos hubungan perempuan dengan alam( Wuriyani dan Udasmoro, 2017).

Setakat ini, disertasi Bernardus Suliantoro menjadi satu-satunya tulisan yang menyorot pengolahan hutan dengan filsafat ekofeminisme. Karya ilmiah ini bertujuan mengeksplisitkan, mengkritisi, menemukan visi baru pemikiran etika ekofeminisme Vandana Shiva dan Karren J. Warren serta mengkontekstualisasikan dengan cara pandang masyarakat setempat. Hasilnya menunjukkan keadilan gender dan kepedulian terhadap lingkungan dapat terwujud jika manusia meninggalkan pola pikir, cara pandang, dan praktik kapitalisme patriarki. Gagasan kedua filsuf yang ia acu sebagai fondasi berpikir memiliki kemiripan, sudah dipraktikkan, dan diberi inovasi baru oleh masyarakat Desa Beji pada saat mengembangkan visi ekofeminisme. Visi ekofeminisme masyarakat tersebut tidak hanya berhenti pada kesetaraan, tetapi hendak melangkah lebih lanjut pada upaya mewujudkan kesejahteraan (Shiva, 2005).

Selain skripsi Reni Agustina, artikel Elly Wuriyani dan disertasi Bernardus tersebut, ada pula penelitian (Hastuti, 2016) yang mengangkat mengenai representasi kultural laki-laki dan perempuan di dalam cerita rakyat "Putri Lungo" Data berupa sebuah prosa, kisah "Putri Lungo", yang dituturkan secara lisan. Analisis dilakukan dengan metode kualitatif menggunakan pendekatan antropologis. Dari hasil analisis diketahui bahwa representasi lakilaki di dalam kisah "Putri Lungo" melekat dalam tokoh Lampae. Seorang laki-laki terutama sekali adalah harus memiliki kemampuan memutuskan sesuatu. Seorang laki-laki harus mempersiapkan diri sebaik mungkin sebelum menerima sebuah tanggung jawab. Ketika sudah memangku tanggung jawab sebagai kepala keluarga, seorang laki-laki harus dapat memenuhi kewajibannya mencari nafkah guna memenuhi kebutuhan keluarga. Sementara itu, perempuan dalam "Putri Lungo" direpresentasikan oleh dua tokoh, yaitu ibu dan Putri Lungo. Di dalamnya terbaca adanya hak bagi perempuan untuk mengajukan permintaan sebagai syarat diterimanya pinangan. Selain itu, perempuan secara kultural mengemban fungsi pendidik di dalam rumah tangganya

Keseluruhan hasil penelitian di atas mengangkat hipotesis dalam tulisan ini, betapa ideologi maskulin dalam prinsip patriarkat sepenuhnya merupakan perspektif yang harus diubah. Perubahan ini tidak bertujuan melemahkan posisi laki-laki lantas memperlebar jurang permusuhan antara manusia dan alam. Implementasi ekofeminisme memiliki luaran yang dimaksudkan untuk menciptakan kesetaraan, kesejahteraan, penanggalan relasi kuasa alam dan manusia-sekaligus laki-laki terhadap perempuan, dan hubungan yang ajek antara manusia dan habitatnya. Kesemuanya menjadi piranti membantu menelaah sejauh mana hubungan alam dan manusia terkontestasi dalam praktikpraktik kehidupan, khususnya yang terjadi dalam masyarakat Moronene melalui cerita rakyatnya.

\section{TEORI}

\section{Genderang Perang Ekofeminisme}

Shiva mengemukakan bahwa ilmu dan teknologi tidak bersifat tak memihak gender(Shiva, 2005). Demikianlah dua konseptor raksasa teori ekofeminisme menabuh perkakas perang terhadap perkembangan dunia. Dunia yang dibungkus kulit ilmu pengetahuan dan jaring-jaring teknologi. Shiva dan Mies sepakat betapa dalam konteks keterkinian masyarakat internasional sedang berada dalam rahim persoalan sebagai akibat dari dampak negatif politik global. Sebuah sistem politik yang bersamanya dominasi kekuatan kapitalis patriarkiyang membuat dunia menjadi homogen dan terfragmentasi dibentuk. 
La Ode Gusman Nasiru: Menyoal Alam, Menjelma Perempuan: Karnaval Kultural Cerita Rakyat Moronene

Meminjam perspektif kedua ekofeminis di atas, kita dapat menilai bahwa sebuah komposisi kapitalis patriarki memenjarakan beberapa entitas dalam sebuah struktur. Struktur sebagai lazimnya perangkat-perangkat yang saling berkaitan akhirnya melahirkan hierarki untuk sampai kepada kondisi yang paling diidamkan. Senyatanya, dalam struktur itu muncul gelembung-gelembung ketidakadilan yang mengangkat dan mengempaskan kelompok tersubordinasi ke sudut kutub kontestasi. Tidak dapat dihindari kemudian mengemuka beragam penindasan sebagai imbas dari pertautan kerangka dikotomis: negara-negara Utara mendominasi negaranegara Selatan; laki-laki mendominasi perempuan; dan semakin banyak penjarahan terhadap sumber daya alam sehingga terwujud ketimpangan dalam distribusi keuntungan ekonomi dalam penguasaan alam (Shiva, 2005: 2).

Mies (via Shiva, 2005: 108) selanjutnya mengangkat wacana tentang bencana Chernobyl di Rusia. Ia menilai ledakan reaktor nuklir ini menjelaskan bahwa energi atom, dan teknologiteknologi masa depan yang baru lainnya, seperti rekayasa reproduksi dan genetika adalah teknologi-teknologi perang. Metodologinya didasarkan pada perusakan hubungan dan simbiosis kehidupan. Sains modern artinya peperangan melawan alam. Alam adalah musuh-perempuan-yang harus melayani laki-laki.

Laki-laki tampaknya ahli dalam bidang teknologi, sementara perempuan ahli mempertahankan hidup. Laki-laki menciptakan perang, dan perempuan yang harus memulihkan kehidupan pascaperang. Pelajaran yang dapat diambil dari bencana nuklir Chernobyl: dampak penerapan mesin modern oleh kaum laki-laki di bumi pada gilirannya akan dirasakan oleh semua orang; semua saling terkait. Kemajuan tanpa batas merupakan mitos yang berbahaya, karena mitos itu menuntun kita untuk merampas dan menghancurkan kehidupan alam.
Tong menuliskan asumsi para enviromentalis yang berorientasi manusia yang meyakini bahwa nilai lingkungan adalah instrumental; maknanya, kepentingannya, dan tujuannya bergantung kepada kebutuhan atau keinginan kita. Lingkungan hidup ada bukan untuk dirinya sendiri, melainkan untuk manusia(Tong, 2010). Pandangan demikian selanjutnya dikelompokkan Tong dengan istilah "ekologi-dangkal". Artinya, ada bentuk etika ekologi lain yang lebih dalam dan krusial.

Ekologi-dalam" merupakan istilah bagi keyakinan pemerhati lingkunganyang berpusat pada bumi. Kalangan ini menolak konsepsi modern yang menempatkan alam sebagai mesin, dan kemudian kembali ke konsepsi terhadap alam Abad Pertengahan, bahkan kuno, yang memposisikan alam sebagai organisme yang mempunyai nilai intrinsik dan instrumen. Leopold (via Tong, 2005) sebagai salah seorang pendukung ekologi-dalam menawarkan sebuah konsep etika lingkungan yang mengalir secara tepat untuk kemudian diistilahkan sebagai "biosentris" atau "ekosentris". Menurutnya, suatu hal adalah benar, jika hal itu cenderung untuk memelihara integritas, stabilitas, dan kecantikan komunitas biotik. Upaya menggantikan antropomorfisme ekologidangkal dengan biosentrisme ekologidalam inilah yang menjadi muasal dari lahirnya pemahaman ekofeminisme.

$$
\text { Susan Griffin melihat }
$$

environmentalisme ekologis atau yang ilmiah menekankan pada arti pentingnya mempertahankan lingkungan biologis atau fisik; dan bahwa lingkungan humanistik menekankan ketidakcocokan ilmu modern dan perkembangan teknologi dengan prinsip-prinsip kemanusiaan. Perspektif ekofeminisme memandang bahwa hidup di alam dipertahankan dengan jalan saling kerjasama, dan saling memberi perhatian dan cinta. Hanya dengan cara itu kita mampu merespon dan menerima keragaman dalam segala bentuknya, termasuk ekspresi kebudayaan, sebagai 
sumber riil kesejahteraan dan kebahagiaan. Tidak heran para ekofeminis kerap menggunakan kiasan "merangkai kembali dunia", "penyembuhan luka-luka", dan menghubungkan kembali jaring-jaring yang mulai kendur (Shiva, 2005)

Di atas telah disinggung bahwa alam adalah oposisi bagi entitas berlabel laki-laki. Posisinya sebagai musuh menjadi alasan ia lantas dieksploitasi dan menyediakan pelayanan prima bagi segala kebutuhan laki-laki. Tong (2010) menilai ekofeminisme berusaha untuk menunjukkan hubungan antara semua bentuk opresi manusia, tetapi juga memfokuskan pada usaha untuk mendominasi dunia bukan manusia, atau alam. Perempuan secara kultural dikaitkan dengan alam. Oleh karena itu, ekofeminis berpendapat ada hubungan konseptual, simbolik, dan linguistik antara feminis dan isu ekologi (Hlm.359).

Hubungan-hubungan yang dijelaskan Tong menjadi induk bagi Candraningrum (2014: 4) menempatkan ekofeminisme sebagai sebuah konsep yang meyakini telah lama perempuan secara kultural dikaitkan dengan alam. Ketika ia terdorong ke dalam ruang partiarki yang kejam, perempuan dan alam dijustifikasi sebagai properti yang layak diopresi. Ia menambahkan modernitas dan kapitalisme sebagai entitas yang telah menceraikan manusia dari kesatuan itu: dari keterkaitan, kesetaraan, aksi kasih sayang, terhadap alam, binatang, dan pohon-pohon (2014: 2).

Manusia yang telah jauh meletakkan identitas dirinya secara superior di atas elemen alam dan hewan yang sejatinya membentuk sirkularitas ekosistem yang padu. Manusia tak lagi dapat mewariskan kesatuan dengan alam, dengan binatang, dengan tumbuhan, dengan pohon-pohon. Dalam konsep yang lebih sederhana, otoritas kultural kemudian membenturkan laki-laki dan perempuan seiring dengan kontestasi yang mereka bangun antara budaya dan alam. Perempuan diindikasikan sebagai alam- yang harus ditaklukkan, sementara lakilaki dikondisikan sebagai budaya-sang penakluk. Tidak pernah ada proposisi yang dengan tangkas menjelaskan relasi dominasi-subordinasi mengenai kapan eksploitasi yang satu berakhir dan yang lainnya dimulai(Nasiru, 2016: 209).

Shiva berkeyakinan sekaranglah saatnya untuk mengakhiri peperangan terhadap alam, sekarang waktunya alam tidak hanya dipandang dan diperlakukan sebagai musuh, tetapi sebagai entitas hidup tempat kita terintegrasi di dalamnya. Jika tidak, kita tidak hanya akan menjadi pengamat reruntuhan es Kutub Utara yang semakin lama makin meluas. Kita, manusia yang angkuh ini, juga kelak menjadi bagian dari reruntuhan: reruntuhan zaman, reruntuhan kosmos.

\section{METODE}

Secara umum, penelitian ini menggunakan metode analisis deskriptif kualitatif. Analisis dilakukan setelah mendeskripsikan data-data yang sudah diidentifikasi lewat proses pembacaan. Data-data tersebut berupa potongan narasi yang sesuai dengan konsep dan teori ekofenisme.

\section{HASIL DAN PEMBAHASAN Laki-laki yang Lemah Daya}

Di atas telah disebutkan bahwa ekofeminisme bekerja menilai opresi yang terjadi di atas tubuh dan kemanusiaan perempuan adalah refleksi dari ekploitasi tanpa batas dari manusia terhadap alam. Filsafat ekofeminisme menilai kecenderungan diskriminasi yang dialami perempuan selanjutnya diasumsikan sebagai sebuah keniscayaan, fenomena sosial yang lazim dan terlalu biasa. Perempuan-perempuan dipaksa menelan takdir mereka dalam wujud ketertindasan yang tak pernah mengenal kata selesai.

Mereka dijajah pria - saya tiba-tiba teringat potongan lagu Sabda Alam karya Ismail Marzuki, dimamah budaya, dikunyah oleh pengasingan-pengasingan dan segenap kesakitan di atas kategorisasi 
gender mereka. Semua kepahitan itu bersumber dari satu muasal dengan keberagaman istilah: laki-laki, budaya, pariarki. Selanjutnya, penting untuk melihat bagaimana laku tokoh laki-laki dalam potongan narasi ketiga cerita teranalisis.

Sepeninggal ibunya, ia selalu menghabiskan waktunya dengan bekerja di kebun sehingga ia makin tersisih dari kehidupan masyarakatnya. Suatu hari, ketika si pemuda sedang membuka lahan baru, ia menemukan sebuah mangkuk putih (TIL: 15).

Izinkan saya melakukan tapak tilas terhadap Firas, tokoh dalam novel Partikel. Deskripsi tentangnya menyiratkan bagaimana ia harus memilih antara dua dunia, tetap menjadi hamba dalam gejolak modernitas masyarakat umum, atau mempertahankan ideologi dan kesadarannya untuk kukuh bertahan dalam dimensi axis mundi. Ia memilih opsi kedua.

Berangkat dari hukum kausalitas, ia harus menerima pengasingan dari masyarakat. Ia dianggap gila karena dinilai terlalu bersenyawa dengan semesta. Sampai di sini, saya perlu garis bawahi, Firas adalah laki-laki. Sekarang mari kita letakkan sekat gender ini ke atas tubuh tokoh yang saya hadirkan melalui nukilan di atas. Kita tidak bisa menghindari kenyataan betapa pertautan yang melekatkan laki-laki dengan kultur atau dinamika sosialnya ternyata bisa saja merenggang. Kita tidak bisa selalu menarik kesimpulan bahwa yang perempuan pasti alam, sementara laki-laki selalu budaya.

Spesies manusia yang membangun kebudayaan tanpa alam terus berusaha menemukan bentuk yang presisi untuk mempertahankan eksistensinya sebagai super ordinat. Tidak peduli cara apa pun yang ditempuh, bahkan bila harus melepaskan satu dua residu yang mereka anggap sebagai tidak bernilai.

Chyntia Enloe (via Shiva, 2005: 142-143) menghadirkan citra Rambo untuk membangun wacana bagaimana umumnya laki-laki berperilaku dalam sistem kemasyarakatan. Ia melihat Rambo sebagai gambaran baru kejantanan modern. Rambo mengejar keuntungan ekonomi dan politik. Ia citra bagi laki-laki yang militeristik dan mengapa militer selalu menyerang perempuan. Logika rambo adalah logika yang patriarki dan bertaruh mempertahankan hidup dengan berdasarkan siapa yang paling kuat.

Tokoh Lampae yang saya nukil di atas memang tokoh laki-laki. Ia selayaknya digolongkan kedalam kelompok budaya, sekaligus antitesis dari alam. Sayangnya, Lampae bukanlah hero yang harus berhadapan dengan musuh, baik perempuan maupun lingkungan. Ia tidak bekerja di ladang industri dan sistem moneter. Ia tidak menghasilkan keuntungan finansial dari laku kesehariannya. Ia tidak sedang menyalakan api konflik dengan siapa pun.

Inilah yang terjadi pada tokoh kita. Laki-laki, tetapi juga tersingkir dari masyarakat. Ia bukan Firas yang punya afeksi terhadap alam. Sekadar menjalankan tugasnya memenuhi hidup dengan bertani, tanpa bayang-bayang mengkomersialisasi hasil ladangnya. Ia tidak tergolong dalam pekerja produktif menurut sistem ekonomi dominan. Lingkaran produksi dan konsumsi yang tertutup menjadikannya hanya sebatas residu,bukan bagian dari sistem sosial dan dinamika kultural.

Ia harus memilih menjadi kawan atau lawan. Sebab dalam ideologi patriarki, tidak ada ruang bagi keanekaragaman. Lampae mengalami reduksi peran sekaligus reduksi eksistensi. Ia tercerabut dari skenario yang selama ini dimainkan. Ia bukan semesta, tetapi juga bukan budaya. Lampae mengalami negasinegasi dari kenyataan sosial yang lazim terjadi. Ia terbuang dan terasing di antara 
dua galaksi besar yang dalam konsep ekofeminisme dikenal sebagai kultur dari komunal dan jagat alam raya.

"Syaratnya adalah engkau
tidak boleh menyampaikan
kepada orang lain bahwa saya
orang kayangan
(Wawosangia)..."
"Baiklah, saya setuju
dengan syaratmu itu Putri
Lungo, saya berjanji tidak
akan membocorkan tentang
asal-usulmu kepada siapapun
juga."
....
"Baiklah tuan, sebenarnya
istri saya ini adalah keturunan
bidadari." (TIL: 16-17).

Logika Rambo akhirnya juga membuka jurang tersendiri bagi laki-laki. Logika ini memangkas struktur paten yang melekatkan dua konstituen: laki-laki dan kultural. Keduanya dibentur-benturkan satu sama lain, sehingga tidak jelas siapa berkawan dengan siapa. Menariknya, kenyataan ini tidak serta-merta memutus benang kenyataan yang tersamarkan.

Bahwa sesungguhnya yang sedang bermain dalam tahapan ini ialah siapa yang berdiri di puncak struktural. Sang Raja yang disapa "tuan" dalam kutipan di atas menimbun eksistensi laki-laki dan menyulapnya menjadi kelompok tidak berdaya. Laki-laki yang saya maksud di sini ialah mereka yang tidak didesripsikan sebagai Rambo, sebagai penguasa, penjajah, atas kelompok yang lain. Tidak bagi perempuan. Tidak bagi alam.

Penguasaan ini buntut dari modus patriarki yang hierarkis dan dikotomis. Penguasaan menjadikan laki-laki dan kulturnya sebagai pihak yang paling berhasrat menyerang gagasan etika lingkungan. Dalam konteks di atas, yang diserang bukan lagi etika lingkungan. Laki-laki dan kulturnya berbalik menyerang diri mereka sendiri. Diri yang juga belum tentu diterima lingkungan biotik. Diri yang tidak berdaya.

Ada seorang laki-laki tua yang setiap hari disapa Ayah Kuma. Tiada pekerjaan menetap selain keluar masuk hutan mencari umbi-umbian yang sudah mulai berkurang untuk menyambung hidup (UNT: 45).

Ketidakberdayaan laki-laki juga terang disuratkan dalam alur hidup Ayah Kuma. Kemiskinan merenggut segala kesombongan laki-laki yang selalu berdiri beberapa tingkat dibanding musuh-musuh mereka. Realitas di atas dapat digunakan sebagai senjata betapa yang kerap berdiri di titik superodinat tidak selamanya bisa mengandalkan kekuatannya untuk menunjang kehidupannya.

Ia memang tidak menjajah alam. Ia bahkan disinyalisasi menjadi bagian dari alam, dengan melakoni sistem produksi yang sekaligus menempatkannya sebagai konsumen dalam lingkaran yang tertutup. Namun, alam tetap punya kuasa atas siapapun untuk menjadi tumbal dari eksistensinya yang tidak tertebak. Kita dapat mengatakan ini semacam proyek balas dendam atas konstruksi sosial magnum opus laki-laki dan kuasa kulturalnya. Hingga kemudian ia harus menyerahkan hidupnya bulat-bulat di telunjuk kekuasaan perempuan.

Pemuda yang datang melamar sudah tidak terbilang jumlahnya sehingga Putri Warema dan keluarganya kesulitan untuk menentukan siapa yang akan dipilih. Apalagi pemuda-pemuda yang datang adalah para ksatria yang jago di medan perang. Raja dan Putri Warma menyadari bahwa jika ada salah satu di antara ksatria yang diterima lamarannya, 
La Ode Gusman Nasiru: Menyoal Alam, Menjelma Perempuan: Karnaval Kultural Cerita Rakyat Moronene

ksatria lainnya akan kecewa dan sakit hati. Hal ini dapat mengakibatkan terjadinya perang saudara (DRK: 85).

Kutipan alur di atas mengingatkan saya pada sikap Shiva(2005: 108) yang meyakini bahwa kepercayaan terhadap peran laki-laki dalam politik dan science adalah berbahaya, semua itu dikarenakan pemikiran mereka tidak didasarkan pada prinsip-prinsip etika. Mereka tidak hanya tidak memiliki etika tetapi juga rendahnya imajinasi dan emosi mereka. Kita tidak bisa berkelit betapa kita hidup di atas tungku situasi sosial yang mengkonstruksi gender lengkap dengan segala diferensiasinya: laki-laki logis dan perempuan emosional. Laki-laki mampu berpikir tentang dirinya sendiri tanpa perempuan, sementara perempuan tidak dapat memikirkan dirinya tanpa laki-laki (Beauvoir, 2003).

Realitas cerita tampaknya menyodorkan fakta betapa laku amoral dan rendahnya tingkat emosional laki-laki justru menjadi salah satu ancaman besar bagi kedamaian dan keberlangsungan hidup semesta. Perkembangan politik dan ilmu pengetahuan yang tidak bebas dari bias gender, seperti yang diteriakkan Shiva dan Mies, pada akhirnya harus disusun ulang dengan mempertimbangkan eksitensi perempuan yang bersama lakilaki menjadi salah satu kelompok yang mengisi bumi-dengan segala kerusakan yang mereka bawa.

Kebocoran pabrik pestisida Union Carbide yang melepaskan empat puluh ton gas beracun menewaskan tiga ribu orang di India bencana Chernobyl di Rusia, danusulan pembangunan pembangkit tenaga listrik nuklir di Whyl, Jerman, menyodorkan data kaitan antara teknologi dan kegilaan pada pertumbuhan yang berorientasi pada keuntungan dari sistem industri serta eksploitasi.. Ketiga bukti perkembangan industri dan teknologi ini menunjukkan bahwa ilmu pengetahuan, laki-laki, dan sistem kultural telah menjadikan perempuan sadar bahwa seluruh paradigma sains adalah karakteristik patriarki, antilingkungan dan kolonial, serta bertujuan menjauhkan perempuan dari daya generatif mereka seperti halnya daya produktif alam.

Bencana dahsyat yang diuraikan Shiva dan Mies nyatanya tidak berbeda dengan alur yang terinternalisasi dalam cerita DRK. Nafsu dari kelompok laki-laki yang tidak mengerti cara bernegosiasi dengan kekecewaan-kekecewaan mereka, cara meredam dan memanfaatkan emosi dalam halaman-halaman kebaikan, juga akan membawa bencana yang tidak kalah mematikannya dengan kehancuran fisik yang dialami kedua negara di atas. Sastra melalui tangan cerita rakyat memang tidak memberikan kepuasaan bagi mereka yang hanya mampu melihat bencana fisik yang nyata. Akan tetapi, sekali kita mengabaikan apa yang telah disarikan berdasarkan riwayat dan spiritualitas nenek moyang yang tertuang dalam aneka kisah fiksi, sebenarnya kita sudah selangkah masuk ke jurang kehancuran. Kita tidak akan pernah mengizinkan diri kita terperosok ke zona itu.

Etnis Moronene, berangkat dari penjabaran di atas, dapat dikatakan cukup unik dalam memandang relasi laki-laki dan perempuan. Dalam ketiga cerita yang dibentangkan, terlihat betapa perempuan selalu mendapat tempat istimewa. Memang ia selalu dipasangkan dengan alam, tetapi tidak lantas ia menjadi kelompok yang tertindas. Ia justru mampu menjaga, melindungi, dan menghidupkan. Kenyataan ini tentu tidak bisa dibilang upaya merebut posisi patron yang selama ini lekat dengan identitas gender laki-laki, tetapi lebih tepat dikategorisasi sebagai ikhtiar mencerabut patok-patok yang memisahkan laki-laki dan perempuan dalam kategorisasi struktural yang hegemonik. Komunal Moronene menolak keras persoalan bias gender yang mengunggulkan jenis yang satu seraya mengenyahkan jenis yang berbeda. Laki- 
laki dan perempuan setara dalam kehidupan.

\section{Perempuan Ibu Pertiwi}

Shiva dan Mies membahasakan hal spritualitas di bab-bab awal pemikiran mereka. Mereka meminjam prinsip Starhawk (via Shiva, 2005: 18-19), spiritualitas sebagaian besar diidentikkan dengan sensualitas perempuan, energi seksual mereka, daya hidup mereka yang paling berharga, yang menghubungkan mereka kepada satu sama lain, kepada bentuk kehidupan dan unsur-unsur yang lain.

$\mathrm{Si}$ pemuda itu melihat seorang gadis yang sangat cantik sedang memasak.

Saya ini jelmaan mangkuk putih yang engkau temukan di kebunmu. Nama saya Putri Lungo.

"Janganlah kamu menyesal telah membongkar asal-usul saya. Ini adalah takdir yang kuasa. Sesuai dengan perjanjian kita [yang] sudah disepakati, saya akan pergi. Satu pesanku, jagalah anak kita baik-baik. Jika mereka rindu padaku, kosongkanlah lesung yang ada di rumah dan saya akan datang dalam bentuk hujan (TIL: 15-17).

Sebelum membahas lebih jauh tentang spiritualisme, saya ingin mengajak Anda menoleh sejenak pada mitologi yang dibangun masyarakat patriarki tentang disparitas antara kerja domestik dan kreativitas di ranah publik. Bagian pertama dari kutipan di atas secara tegas memerikan pembagian tanggungjawab antara laki-laki dan perempuan. Sebuah upaya melanggengkan dikotomisasi antara dua kelompok gender yang saling dikontestasi.
Alur yang mendeskripsikan pemuda sebagai entitas yang disibukkan dengan penggarapan kebun sekaligus menempatkan perempuan dalam perannya sebagai sebatas pengasuh dalam sistem rumah tangga. Pemisahan ini kedengarannya paradoks dengan usaha pengakuan perempuan sebagai bagian dari alam, yang menghidupkan tetapi sekaligus dibajak, dalam konsep ekofeminisme. Akan tetapi, pembahasan justru akan bergerak lebih jauh dari itu. Sebab, kerja perempuan yang menyiapkan bahan makanan, dari proses produksi hingga konsumsi, tidak pernah dianggap sebagai kerja produktif dalam kerangka ekonomi industri yang tidak bernilai komersil. Hal ini pernah disinggung pada subjudul sebelumnya.

Dari bangunan asumsi tersebut, kita bisa berangkat lebih jauh tentang distingsi antara kedua gender teranalisis. Dalam pengertian mistis, dari Beauvoir (2003), bumi diasumsikan sebagai milik kaum perempuan: menurut agama sekaligus hukum, mereka menguasai tanah beserta segala isinya. Ikatan antara perempuan dan tanah sejatinya dicirikan oleh asimilasi nyata perempuan dengan bumi; pada kedua kelangsungan hidupyang secara esensial adalah keturunandilakukan melalui reproduksi berbagai perwujudan individunya, berbagai avatarnya (Hlm. 98-103). Itulah kenapa, Putri Lungo dinarasikan sebagai "jelmaan" dari mangkuk putih.

Pemahaman ini tidak sekadar menyorot perempuan dengan teleskop "kealaman", melainkan sekaligus melihat laki-laki sebagai pihak oposisi. Masyarakat pasti selalu berjenis laki-laki; kekuasaan politik selalu berada di tangan laki-laki. Otoritas selalu merupakan hak prerogatif sebuah kelompok. Otoritas merupakan perwujudan dari Diri Yang Tunggal. Segala yang berdiri di luar lingkaran adalah tidak transenden. Mereka ini yang kerap dikelompokkan sebagai kelas subordinasi. Merekalah perempuan. 
La Ode Gusman Nasiru: Menyoal Alam, Menjelma Perempuan: Karnaval Kultural Cerita Rakyat Moronene

Keperempuanan melempar kita kembali pada pemaknaan tentang spiritualitas. Materialisme Marxis dan Kapitalis, memandang pencapaian kebahagiaan manusia sebagai syarat mendasar dari perluasan produksi barang materiil. Semua materi yang bernilai dalam sistem produksi dengan prinsip keuntungan finansial adalah hal utama. Kepentingan ini sekaligus menyangkal dimensi dan signifikansi yang lain, yakni spritualitas. Sementara itu, spiritualitas dipercaya sebagai preferensi dari perempuan. Kendati spirit adalah nilai dari keperempuanan, ia tidak terpisah dari dunia materiil. Ia terintegrasi ke dalam dunia keseluruhan prinsip materialisme. Keduanya saling mengisi.

Spiritualitas adalah kasih yang magis dan dapat mempengaruhi laki-laki yang perkasa. Itu sebabnya, Tina Lungo memiliki nilai dan kekuatan untuk mengajukan persyaratan yang harus dipenuhi oleh calon suminya. Sayangnya, fakta cerita menyuguhkan peristiwa tentang ketidakmampuan sang suami memenuhi persyaratan yang telah ia ikrarkan di awal cerita. Sang suami tidak punya pilihan kecuali membeberkan dari mana asal-usul istrinya. Ketidakmampuan inilah yang diasumsikan sebagai ketidakberdayaan laki-laki.

Jika kita meneropong tokoh Raja Tangkeno yang memaksa untuk mengetahui asal-usul Tina Lungo, kita juga bisa bersepakat bahwa sang raja yang mewakili kelompok laki-laki ternyata tidak dapat menerima perbedaan dan keberagaman. Segalanya harus seragam demi memenuhi kepentingannya. Ia menolak pencampuran manusia dan bukan manusia, ia menolak pencampuran antara yang materiil dan yang spiritual. Sang Raja berdiri sebagai representasi dari sistem yang selalu ingin menjadi tunggal demi mencapai puncak dari undakan-undakan hierarkis. Shiva (2005) melihat keangkuhan ini sebagai wujud ketidakmampuan melihat alam melaui nilai intrinsik yang terkandung di dalamnya, melainkan lewat eksploitasi ekonomi demi mendapatkan keuntungan komersial (Hlm.189).

$$
\begin{aligned}
& \text { Tiba-tiba laki-laki tua itu } \\
& \text { berjumpa dengan seorang } \\
& \text { perempuan cantik. Itu adalah } \\
& \text { Dewi Padi, namanya } \\
& \text { Wa'uraa. Pada saat ia } \\
& \text { bertemu, perempuan cantik } \\
& \text { itu berjanji kepada laki-laki } \\
& \text { tua tidak usah lagi mencari } \\
& \text { umbi-umbian di hutan. }
\end{aligned}
$$

Setelah tempat-tempat itu rapi, tidak lama kemudian mereka melihat tempat itu pun sudah terisi.

Perempuan cantik itu pun datang dengan memberikan sebuah [bibit padi dalam] bungkusan kecil dari kulit jagung. Berikutnya, laki-laki tua itu menanam padi tersebut. Padi itu pun setelah ditanam lalu berbuah.

"Bangunlah, potonglah padi yang sudah kau tanam itu, carilah orang-orang sebanyak-banyaknya supaya mereka memotongkan padimu."

....

Begitulah kegiatan yang mereka lakukan sehingga mereka pun tidak dapat lagi mengurus padi-padi itu sehingga membusuk (UNT: 45).

Perbincangan tentang spiritualitas yang terbangun atas relasi alam dan perempuan juga terinklusi ke dalam narasi UNT. Dinyatakan secara eksplisit oleh Candraningrum (via Endraswara, 2016: x) relasi spiritualitas perempuan dan alam terdiri atas relasi harfiah dan simbolis. Harfiah karena perempuan ditempatkan di 
wilayah domestik (rumah) sebagai efek budaya patriarki. Sedangkan simbolis, karena ia bisa mengacu pada pelabelan sifat-sifat feminin yang berkesan subordinatif dan istilah yang mengacu pada penjadian objek untuk alam, yang mulanya diletakkan pada perempuan: pemerkosaan hutan dan eksploitasi tambang (Hlm.189.

Relasi ini menjadi sebab bagi lahirnya mitologi-mitologi tentang dewi kemakmuran di tanah air, contohnya Dewi Sri. Kutipan panjang yang saya nukil di atas secara telanjang menyodorkan peran sang dewi yang menjadi simbol sastra hijau. Dewi Sri mewarnai peristiwa kesuburan orang Jawa, tetapi lebih sering hidup dengan nama yang berbeda di daerah lain dengan mengusung filsafat yang sama. Simbol tokoh heroine bagi etika pemikiran ekologis dalam UNT diwakili oleh Wa'uraa.

Endraswara

(2016:

menjelaskan bahwa transendensi Dewi Sri dilandasi oleh ideologi femininitas dan maskulinitas. Prinsip feminin di sini memosisikan diri ke dalam perspektif dan agenda persoalannya seluruh persoalan etnis, perjuangan kelompok minoritas dan kelompok masyarakat yang tergusur untuk memperoleh hak hidup dalam kelompoknya sebagai kesatuan otonom dalam perikehidupan sosial.

Riak-riak kontradiktif barangkali akan muncul melalui klausa "padi dibiarkan membusuk". Dalam kategori ekonomi produktif, hal demikian akan mengisi sebuah kantong yang bernama kerugian. Prinsip produksi semacam itu tidak akan pernah memahami bahwa alam memiliki cara tersendiri untuk menghayati tugasnya, termasuk sebagai agen pembebasan. Mengapa demikian?

Padi yang membusuk bisa digeser menjadi pakan tikus, tikus yang menghidupkan ular, dan kita akan kembali merayakan mata rantai makanan dalam gugus piramida. Padi yang membusuk kelak menjadi humus, menghidup cacing dan memperbaiki unsur hara dalam tanah.
Tanah yang selanjutnya digali dan dibajak demi menghidupi benih padi untuk manusia. Prinsip pertanian yang diukir di atas tubuh materialisme Marxis dan Kapitalis yang bersandar pada filsafat keuntungan finansial tidak akan memahami bahwa kita terekam dalam siklus semesta yang menghidupi, yang merawat, yang transenden.

Untuk menghindari terjadinya
musibah yang lebih besar,
Purri Warema memutuskan
untuk bunuh diri dengan cara
minum racun.
...
"Jika saya wafat, jangan
makamkan saya di tempat
pemakaman umum tapi
makamkanlah saya di
pekarangan rumah. Jika
tumbuh tanaman baru,
peliharalah tanaman itu
dengan baik."

Pohon tersebut bisa digunakan untuk berbagai keperluan, seperti lidinya untuk sapu, bunganya untuk kolang-kaling, dan sebagainya.

Dari tebasan itu keluarlah air yang rasanya manis. Air yang keluar pun tersebut ditampung dan ketika peringatan hari ulang tahun Putri Warema, air itu dibagibagikan kepada semua pemuda yang dulu pernah datang melamar (DRK: 86).

Dalam kerangka pembebasan, lingkungan ekologis tidak hanya bekerja mendaur ulang tumbuhan, ia juga mengindependensi perempuan dari kebudayaan laki-laki yang penuh amarah dan bersifat merusak sekaligus menguasai. Putri Warema dalam narasi DRK menghayati benar peran bumi yang ia 
yakini sebagai axis mundi. Ia lebih memilih menyerahkan jasadnya kepada pelukan semesta, kepada Sang Ibumeminjam istilah Candraningrumtinimbang harus menyerahkan nasibnya pada sungai pertumpahan darah yang digenangi nafsu kehidupan yang artifisial dari laki-laki.

Mary Daly (via Tong, 2010) melihat proses pembebasan perempuan dengan menempatkan kembali perempuan untuk berhubungan dengan dunia awal perempuan yang alami, "bernafsu", dan "liar", serta membebaskan perempuan dari laki-laki yang "mendomestifikasi" dan "menghancurkan" jiwa kultural. Kekuatan perempuan yang memberikan kehidupan dikontraskan dengan kekuatan laki-laki yang berhubungan dengan kematian, imbuhnya (Hlm. 374).

Perempuan mempunyai kapasitas kehidupan manusia yang sepenuhnya, sementara laki-laki hanyalah parasit yang menghabiskan energi perempuan. Kita bisa menoleh kembali pada pemikiran Udasmoro(2012: 65) tentang cerita-cerita dari Barat semisal Cinderela, Putri Tidur, atau Putri Salju yang masih pula dibaca oleh anak-anak. Cerita-cerita ini lebih mengisahkan seorang putri yang pasif yang menunggu datangnya pangeran penyelamat. Kisah-kisah itu melegitimasi kondisi perempuan-perempuan di zamannya, mencerminkan kehidupan perempuan-perempuan yang hanya mampu menerima dan meratapi nasib tanpa kekuasaan untuk menolak itu semua dan membalikkannya menjadi sebuah kebahagiaan.

Berbeda halnya dengan Putri Warema. Tampaknya kita harus benarbenar bersepakat dengan apa yang telah Daly utarakan. Dalam fakta cerita, sang putri diidentifikasi mampu berpikir dan bertindak menggunakan kecantikannya untuk menyelamatkan nyawa manusia yang hendak berperang. Ia menjaga kehidupan seluruh masyarakat sebagai penghuni alam semesta. Sebagaimana Merapi yang dianggap Ibu dalam kultur masyarakat Keningar, Putri Warema juga mengabdikan dirinya menjadi Ibu bagi kehidupan yang hendak dilukai oleh gejolak nafsu yang menyalakan api perang di dada para ksatria yang memperebutkannya.

Saya terkesan pada narasi Nadya Karima yang menyorot simbol Ibu Pertiwi dalam tokoh Maleficent yang ia paparkan. Sang tokoh menjaga harmonisasi alam, membangun duri dan pepohonan rapat demi melindungi jantung hutan Moors dari invasi Raja Stevan sebagai simbol keserakahan manusia. Spirit Ibu Pertiwi juga nyata diaktualisasikan Putri Warema. Ia menjelma Goddess, melindungi ketentraman dan kedamaian negerinya dari amuk konflik dan perseteruan. Persembahannya tidak putus bahkan sampai ia mati.

Dari sulur-sulur nasibnya, dari saripati jasadnya, masyarakat hidup memanfaatkan pohon yang seluruhnya memiliki nilai guna, baik batang, daun, maupun buahnya. Ia memberi makan dan penghidupan bagi masyarakat, bagi lakilaki, yang menyadap tubuhnya, mengunyah segenapnya, memamah seluruhnya. Kematiannya menyiratkan bahwa manusia merupakan bagian integral dari alam, bukan subjek otonom dan "di atas" alam.

Masyarakat Moronene, berdasar pada alur wacana yang disuguhkan DRK, sadar betul bahwa relasi yang dekat dengan alam tampak dalam pendasaran moralitas hidup dari kekuatan-kekuatan alam transendental yang melahirkan etika naturalistik di mana perilaku manusia direfleksikan berasal dan tertuju pada alam. Nilai-nilai inilah yang menjadi bingkai dari mitologi dan terintegrasi dalam relasi sebagai mikrokosmos masyarakat Moronene dan makrokosmos dalam lapis-lapis semesta (Endraswara, 2016: 228). Kesadaran ini sepaket dengan konsekuensi tentang kebergantungan pada alam, sekaligus kewajiban mencintainya dengan segenap kesadaran spiritual yang Ilahi. 


\section{PENUTUP}

Para pemikir ekofeminisme spiritual sepakat bahwa ada konektivitas yang lekat antara manusia dan alam. Semakin kita memahami bahwa kita adalah alam, semakin kita akan memahami kesatuan kita dengan segala sesuatu yang ada: manusia, siklus dan proses alam, binatang, tumbuhan.

Kesepadanan alam-manusia ini tersaji dalam alur hidup tokoh-tokoh perempuan teranalisis. Putri Lungo, Wa'uraa, dan Putri Warema masingmasing berdiri sebagai delegasi kaum perempuan yang di atasnya laki-laki dan budaya patriarki kerap menguburnya dengan setimbunan konotasi tentang gender yang teropresi dan subordinat. Mereka pantas disebut sebagai corong bagi suara-suara yang telah lama hilang dari masyarakat modern yang bernapas dengan udara yang bernama industri dan komersialisasi.

Masyarakat Moronene cukup unik memandang relasi laki-laki dan perempuan. Dalam ketiga cerita, terlihat betapa laki-laki selalu mendapat peranperan dekonstruktif: Lampae hidup dalam kegamangan, antara dua titik pijak, kultur dan lingkungan biotik; Ayah Kuma hidup dalam ketuaan dan kemiskinan; para ksatria hidup dalam api birahi yang menjadi jalan masuk bagi kebencian dan peperangan. Di sisi lain, perempuan selalu mendapat tempat istimewa. Memang mereka selalu dipasangkan dengan alam, tetapi tidak lantas menjadi kelompok yang tertindas. Mereka justru mampu menjaga, melindungi, dan menghidupkan. Kedekatan perempuan dengan alam memberi simbol yang kuat betapa masyarakat terkaji cenderung menempatkan alam sebagai ruh bagi geliat kulturalnya, bukan sebagai kompetitor dalam gelanggang seteru yang tidak menghasilkan apa-apa.

Ekofeminisme menjadi piranti paling jitu mengulik permasalahan disparitas atas empat komponen yang kita kenal dengan lema perempuan, laki-laki, alam, dan kebudayaan. Masing-masing bagian dikawinkan dengan satu bagian lain untuk didudukkan pada dua wilayah yang saling berseberangan dengan pasangan lainnya. Hasilnya, benturan-benturan maha dahsyat lahir sebagai kekuatan yang tidak bisa dihindarkan; yang

menghancurkan. Hingga kemudian masing-masing pasangan berdiri sebagai musuh atas bagian yang lain. Divergensi, betapapun, lahir sebagai imbas dari ambisi manusia menguasai dunia bukan manusia, dalam hal ini alam.

Untungnya ketiga cerita yang saya analisis tidak terjebak dalam pertarungan demikian. Ada perspektif segar yang ditawarkan. Perspektif naturalistik menjadi filsafat dan ideologi dalam fenomena sosiokultural masyarakat Moronene. Lingkungan biotik diyakini sebagai axis mundi, ia eksis dalam arena imanensi sekaligus menjadi transenden. Alam menjadi dasar spiritualitas kelompok masyarakat, tidak saja bagi perempuan tetapi juga laki-laki. Ia ruh dan fokus tempat segala bermula dan berakhir, setidaknya itu yang terlihat dalam TIL, UNT, dan DRK.

Ini tentu angin segar bagi para kelompok feminis. Sekaligus menjadi pertanda betapa cerita-cerita yang berkembang dalam tradisi literasi etnis Moronene ampuh menjadi media pembelajaran bagi anak-anak dalam perspektif kultural. Sesuai dengan spekulasi Sarumpaet (2010: 19) yang meyakini bahwa karya-karya tradisional berisi kebijaksanaan, kasih sayang, dan impian sebuah kelompok atau komunitas yang menjadi milik bersama, bahkan menjadi acuan hidup mereka.

Keberagaman pesan dan ideologi dalam ketiga narasi teranalisis menjadi seumpama karnaval di tengah menjamurnya cerita-cerita yang ditelan anak-anak, yang kosong makna dan cenderung mendorong anak-anak ke lembah kekerasan, kelicikan, dan permusuhan. Ketiga cerita teranalisis sejatinya memiliki daya kontemplatif guna 
La Ode Gusman Nasiru: Menyoal Alam, Menjelma Perempuan: Karnaval Kultural Cerita Rakyat Moronene

menumbuhkembangkan kesadaran ekologis dan gender dalam benak anakanak. Sebuah kisah sejatinya mengandung harapan tentang kebaikan dan kebijaksanaan demi membekali anak-anak menjadi manusia yang arif dan menyadari posisinya di kemahaluasan semesta raya.

\section{DAFTAR PUSTAKA}

A.D., F. (2016). Cerita Rakyat Moronene (F. A.D. (ed.)). Kantor Bahasa Sulawesi Tenggara.

Agustina, R. (2012). Citra Tokoh Utama Perempuan dalam Dongeng Das Mädchen Ohne Hände Dan Die Kluge Else dari Kumpulan Dongeng Brüder Grimm: Kajian Feminisme. Unveristas Negeri Yogyakarta.

Beauvoir, S. De. (2003). Second Sex, Fakta dan Mitos (Diterjemahkan oleh Toni B. Febriantono). Pustaka Promethea.

Candraningrum, D. (2014). Ketika Banteng Tak Lagi Minum Air di Bawah Pohon Keningar: Mitos Perempuan Lereng Gunung Merapi. In EKOFEMINISME II Narasi Iman, Mitos, Air \& Tanah. Jalasutra.

Elly Prihasti Wuriyani, Wening Udasmoro, L. S. (2017). Negosiasi Mitos Hubungan Perempuan dengana Alam dalam Teks Opera Batak Perempuan di Pinggir Danau Karya Lena Simanjuntak (Tinjauan Ekofeminisme). Jurnal Lingua, III(2).

Endraswara, S. (2016). Metodologi Penelitian Ekologi Sastra: Konsep, Langkah, dan Penerapan. CAPS.

Hastuti, H. B. P. (2016). "Representasi Kultural Laki-Laki dan Perempuan dalam Kisah Putri Lungo" dalam jurnal Telaga Bahasa Volume 4(2), 187-206.
Karima, N. (2014). Ekofeminisme dalam Sinema Maleficent. Jurnal Perempuan.

Nasiru, L. O. G. (2016). Membincang Ekofeminisme yang Ramah Gender dalam Partikel Karya Dewi Lestari. In Wiyatmi (Ed.), Sastra Hijau dan Ekofeminisme. Universitas Negeri Yogyakarta.

Rambe. (1969). Adat Perkawinan Moronene: Dalam Upaya Melestarikan Kebudayaan Suku Moronene. Tidak Diterbitkan.

Shiva, V. (2005). Ekofeminisme: Persektif Gerakan Perempuan \& Lingkungan (Diterjemahkan oleh Kelik Ismunanto dan Lilik). IRE Press.

Tong, R. P. (2005). Feminist thought. pengantar komprehensif kepada arus utama pemikiran feminis (A.P Prabasmoro, Penerjemah) (2010th ed.). Universitas Gadjah Mada Press.

Tong, R. P. (2010). Feminist Thought: Pengantar Paling Komprehensif kepada Aliran Utama Pemikiran Feminis (A. P. Prabosmoro (ed.)). Jalasutra.

Udasmoro, W. (2012). Sastra Anak dan Pendidikan Karakter. Universitas Gadjah Mada. 
Telaga Bahasa Vol. 8, No. 1, April 2020 